\title{
ASSESSMENT OF GENETIC STABILITY OF MICROPROPAGATED Eucalyptus globulus Labill HYBRID CLONES BY MEANS OF FLOW CYTOMETRY AND MICROSATELLITES MARKERS ${ }^{1}$
}

\author{
Leandro Silva Oliveira ${ }^{2 *}$, Aloisio Xavier ${ }^{3}$, Wagner Campos Otoni ${ }^{4}$, José Marcello Salabert Campos ${ }^{5}$, \\ Lyderson Facio Viccini ${ }^{5}$ and Elizabete Keiko Takahashi ${ }^{6}$
}

\footnotetext{
${ }^{1}$ Received on 01.11.2013 accepted for publication on 22.11.2015.

${ }^{2}$ Universidade Federal de Viçosa, Programa de Pós-graduação em Ciência Florestal, Viçosa, MG - Brasil. E-mail: $<$ leandroengflor@gmail.com>.

${ }^{3}$ Universidade Federal de Viçosa, Centro de Ciências Agrárias, Departamento de Engenharia Florestal, Viçosa, MG - Brasil. E-mail: <xavier@ufv.br>.

${ }^{4}$ Universidade Federal de Viçosa, Centro de Ciências Biológicas e da Saúde, Departamento de Biologia Vegetal, Viçosa, MG

- Brasil.E-mail: <wotoni@ufv.br>.

${ }^{5}$ Universidade Federal de Juiz de Fora, Instituto de Ciências Biológicas, Departamento de Biologia, Juiz de Fora, MG - Brasil. E-mail: <jose.campos@ufjf.edu.br>and <lyderson.viccini@ufjf.edu.br>.

${ }^{6}$ Celulose Nipo-Brasileira S.A. - CENIBRA, BELO ORIENTE, MG - Brasil. E-mail: <elizabete.takahashi@cenibra.com.br>.

*Corresponding author.
}

\begin{abstract}
Flow cytometry and microsatellite markers were used to determine a genetic fidelity of micropropagated plants from the two Eucalyptus urophylla $\mathrm{x}$ E. globulus clones and a Eucalyptus grandis $\mathrm{x}$ E. globulus clone derived from adult material. Clones were repeatedly subcultured for 25 subcultures on MS medium supplemented with BA $(2.22 \mu \mathrm{M})$ and ANA $(0.05 \mu \mathrm{M})$ for in vitro shoot multiplication. The elongation was performed in MS culture medium supplemented with AIB $(2.46 \mu \mathrm{M})$ and BA $(0.22 \mu \mathrm{M})$. The ex vitro rooting and acclimatization phases were lead at the same time. The micropropagated clones showed genetic stability by flow cytometry and microsatellite markers. The results proved that micropropagation, for purposes of rejuvenation, can be a viable technique to generate genetically stable or identical E. globulus hybrid clones.
\end{abstract}

Keywords: Micro-cutting technique; Growth regulators; Genetic fidelity.

\section{AVALIAÇÃO DA ESTABILIDADE GENÉTICA DE CLONES HÍBRIDOS DE Eucalyptus globulus Labill POR MEIO DE CITOMETRIA DE FLUXO E MICROSSATÉLITES}

\begin{abstract}
RESUMO - A citometria de fluxo e os marcadores microssatélites foram utilizados para avaliar a fidelidade genética de plantas micropropagadas de dois clones de Eucalyptus urophylla $x$ E. globulus e um clone de Eucalyptus grandis $x \boldsymbol{E}$. globulus, provenientes de material adulto. Os clones foram multiplicados in vitro em 25 subcultivos sucessivos em meio de cultura MS suplementado com BA (2,22 $\mu M)$ e ANA (0,05 $\mu M)$. O alongamento das brotações foi obtido no meio MS acrescido de AIB $(2,46 \mu M)$ e BA $(0,22 \mu M)$. O enraizamento ex vitro e a aclimatização foram realizados conjuntamente. Os clones micropropagados demonstraram estabilidade genética através das análises de citometria de fluxo e de marcadores microssatélites. Os resultados revelaram que a micropropagação com fins de rejuvenescimento clonal, corresponde a uma técnica viável quanto à obtenção de clones híbridos de $\boldsymbol{E}$. globulus, geneticamente estáveis.
\end{abstract}

Palavras-chave: Microestaquia; Reguladores de crescimento; Fidelidade genética. 


\section{INTRODUCTION}

Eucalyptus globulus hybrid clones can be an alternative to pulp and paper industry because of the good productivity, excellent technological characteristics of wood and adaptability to warmer regions climate conditions (Borges et al., 2011). The increasing interest for commercial companies by these clones resulted in establishment of breeding programs for selecting superior genotypes. However, trees are selected in mature phase and maybe there are differences in vegetative propagation of clones because with aging E. globulus hybrid clones have difficulties on rooting by mini-cutting technique, with high variability in rooting ability.

Thus, the micropropagation is a tool indicted to overcome the difficulty of propagating through conventional methods, especially when there is a high degree of maturation of genetic material (Gomes and Canhoto, 2003). Specifically for Eucalyptus micropropagation via axillary bud proliferation has been used to rejuvenate clones with difficulties in inducing adventitious rooting (Mankessi et al., 2009; Xavier et al., 2013).

Micropropagation, by preformed structures such as axillary buds, is used to promote the rejuvenation of Eucalyptus. This method circumvents dedifferentiation or redifferentiation of cells that occur in other methods for in vitro propagation (Negi and Saxena, 2010). However, there is the possibility of somaclonal variation that occuring in this method (Rani and Raina, 2000; Tripathi et al., 2006), especially with the increasing number of in vitro subcultures (Bairu et al., 2006).

Genetic stability is a major requirement for micropropagation of any species (Chandryka et al., 2010). The possibility of somaclonal variation in micropropagated plants is because of high number in vitro subcultures, changes in relationship auxin/ cytokinin, explant type (Modgil et al., 2005), high concentrations of growth regulators (Bairu et al., 2006) and also by oxidative stress provoking the free radicals production, which damage DNA (Jackson et al., 1998).

Somaclonal variation is manifested by DNA methylation, chromosome rearrangements or punctual mutations (Phillips et al., 1994). Alterations resulting from somaclonal variation are heritable, transmitted by meiosis and often irreversible (Tremblay et al.,
1999). Therefore, the assessment of genetic integrity of the micropropagated plants is important to obtain genetically uniform materials by cloning, while using different techniques of micropropagation (Joshi and Dhawan, 2007; Borchetia et al., 2009; Bhatia et al., 2011). However, the assessment of the genetic stability of micropropagated plants compared to mother plants has been little studied (Leva and Petruccelli, 2012).

Somaclonal variation and guarantee completely genetic fidelity (Mallón et al., 2010) can't be detected by any techique. Therefore, the adoption of different methodologies is necessary to assess genetic stability of micropropagated plants (Peredo et al., 2009). According to Brito et al. (2010), flow cytometry and microsatellites markers are among the most commonly used techniques to assess somaclonal variation. Flow cytometry to determine accurately and quickly, the amount of DNA in large numbers of cells (Loureiro et al., 2005; Orbovic et al., 2008) provide an excellent alternative to assess the genetic stability (Jin et al., 2008). The change in ploidy level is the main genetic variation that occurs in plant tissue culture (Mallón et al., 2010) and flow cytometry has been effective in detecting this type of variation (Brito et al., 2010). Genetic stability several woody species was performed by flow cytometry (Conde et al., 2004; Loureiro et al., 2005, 2007; Brito et al., 2010), including Eucalyptus (Pinto et al., 2004).

Molecular markers are also considered as one of the most useful tools for assessing the genetic uniformity of the micropropagated plants (Bindiya and Kanwar, 2003; Joshi and Dhawan, 2007). Among others, microsatellites markers can be used to detect somaclonal variation in micropropagated plants. The probability of polymorphisms due differences in the number tandem repeats sequences at a specific microsatellite locus is higher than the occurrence of point mutations (Wilhelm et al., 2005; Agarwal et al., 2008; Bairu et al., 2011). So, the microsatellite markers are useful for refined genetic analysis (Lopes et al., 2006) providing high reliability of the results obtained regarding the genetic stability, besides being a rapid and practical analysis (Lopes et al., 2009; Brito et al., 2010).

Although micropropagation of Eucalyptus spp. has been previously reported in the literature, published studies did not assessed in detail the genetic stability of in vitro subcultured plants by axillary bud proliferation for long periods of time, except only the work of Rani and Raina (1998). 
Our study aim is to investigate whether the protocol used for E. globulus hybrid clones axillary bud proliferation from mature plants induces somaclonal variation. So, we employed the flow cytometry and microsatellite DNA markers to evaluate the genetic fidelity of micropropagated clones. Furthermore, the genetic analysis provides a basis for in vitro rejuvenation of E. globulus hybrid clones.

\section{MATERIALS AND METHODS}

\subsection{Plant material}

Two Eucalyptus urophylla x E. globulus (C04 e C16) clones and a Eucalyptus grandis x E. globulus (C30) clone selected in the breeding program of the Celulose Nipo-Brasileira (CENIBRA) pulp and paper company, located in Belo Oriente, Minas Gerais, Brazil were analyzed.

\subsection{In vitro establishment}

Micropropagation for E globulus hybrid clones was established from nodal segments collected of mini-stumps established in mini-clonal hedge, as described by Borges et al., (2011). Briefly, the protocol follows. The nodal segments were prepared from collected shoots. The explants were surface sterilized and inoculated on MS culture medium (Murashige and Skoog, 1962), White vitamins (WHITE, 1943) supplemented with $2.22 \mu \mathrm{M}$ 6-benzylaminopurine (BA), $0.01 \% \quad(\mathrm{w} / \mathrm{v}) \quad m y o$-inositol $\quad 0.08 \% \quad(\mathrm{w} / \mathrm{v})$ polyvinylpyrrolidone (PVP-30) and 3\% (w/v) sucrose (Figure 1D).

\subsection{Shoot multiplication and elongation}

Clumps of shoots, standardized with three shoots bigger than $5 \mathrm{~mm}$ were used as explants in multiplication phase. Explants were inoculated on MS culture medium supplemented with $2.22 \mu \mathrm{M}$ BA, $0.05 \mu \mathrm{M}$ $\alpha$-naphthalene acetic acid (NAA), $0.01 \%$ (w/v) myoinositol, $0.08 \%(\mathrm{w} / \mathrm{v})$ polyvinylpyrrolidone (PVP-30) and $3 \%(\mathrm{w} / \mathrm{v})$ sucrose. Clones used were subcultured 25 times in the multiplication phase. The subcultures were performed every 30 days by transferring shoots to the fresh medium with same composition (Figure 1E).

Shoot elongation was performed with shoots of C04, C16 and C30 clones with 15, 18 and 14 subcultures respectively, in the multiplication phase. Explants comprising three buds were arranged in groups of
4 explants per $40 \mathrm{ml}$ glass ûask on the MS culture medium to elongate (Figure 1F). Both media were supplemented with $2.46 \mu \mathrm{M}$ indolebutyric acid (IBA), $0.22 \mu \mathrm{M}$ BA, $0.01 \%$ (w/v) myo-inositol $0.08 \%$ (w/v) polyvinylpyrrolidone (PVP-30) and $3 \%(\mathrm{w} / \mathrm{v})$ sucrose.

The total media used in the experiment had their $\mathrm{pH}$ adjusted to $5.7 \pm 0.1$, with $0.1 \mathrm{~N} \mathrm{HCl}$ and $0.1 \mathrm{~N}$ $\mathrm{NaOH}$ and $0.7 \%(\mathrm{w} / \mathrm{v})$ agar $\left(\mathrm{Merck}^{\circledR}\right)$ was added as a gelling agent before autoclaving $\left(\right.$ at $121^{\circ} \mathrm{C}, 1.1 \mathrm{~atm}$, $20 \mathrm{~min}$ ). In different micropropagation stages, the cultures were kept in culture room conditions, at temperatures of $26 \pm 2{ }^{\circ} \mathrm{C}$ under a $16 \mathrm{~h}$ photoperiod, with $36 \mu \mathrm{mol}$ $\mathrm{m}^{-2} \mathrm{~s}^{-1}$ irradiance from two ûuorescent tubes (Luz do Dia Especial, 20 W; Osram, São Paulo, Brazil).

\subsection{Acclimatization and micro-clonal hedge formation}

In vitro-grown elongated shoots of E. globulus hybrid clones that reached $2.0 \mathrm{~cm}$ in length were transferred to plastic pots $(11 \times 11 \mathrm{~cm})$ containing $200 \mathrm{~cm}^{3}$ of mixture, composed of vermiculite with

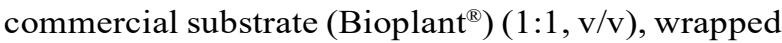
in plastic bags $(12 \times 25 \mathrm{~cm})$ (Figures $1 \mathrm{G}-\mathrm{H})$. The rooted micro-cuttings were transferred to conical plastic tubes $\left(55 \mathrm{~cm}^{3}\right)$ with a commercial substrate (Bioplant ${ }^{\mathbb{R}}$ ) and then were transferred to a greenhouse (air temperature and relative humidity of $28^{\circ} \mathrm{C}$ and $80 \%$ ), for a 30 days acclimatization period (Figure 1I). After this time, micro-cuttings were transferred to a greenhouse with $50 \%$ shade, until reaching $10 \mathrm{~cm}$ size, for planting in gutters containing sand and with a semi-hydroponic system to the formation of the micro-clonal hedge (Figure 1J, K and L).

\subsection{Flow cytometry analyses}

Leaves from mini-stumps, micro-stumps and in vitro plants were collected, maintained in moistened paper and analysed within a maximum period of days. Approximately 20-30 mg fresh leaf tissue from each plant was finely chopped with a disposable steel razor blade in $1 \mathrm{ml} \mathrm{LB} 01$ buffer to release nuclei (Doležel and Bartoš, 2005). Glycine max 'Polanka' (2C DNA content $=2.50 \mathrm{pg}$ ) was used as an internal reference standard (Doležel et al., 1994). Previously macerated tissues were aspirated through two layers of cheese cloth using a plastic pipette, filtered with $50-\mu \mathrm{M}$ nylon mesh, and collected in a polystyrene tube. The suspension was stained with $25 \mu \mathrm{L}$ propidium iodide solution $(1 \mathrm{mg} / \mathrm{ml}$;

Revista Árvore. 2017;41(1):e410114

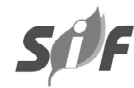




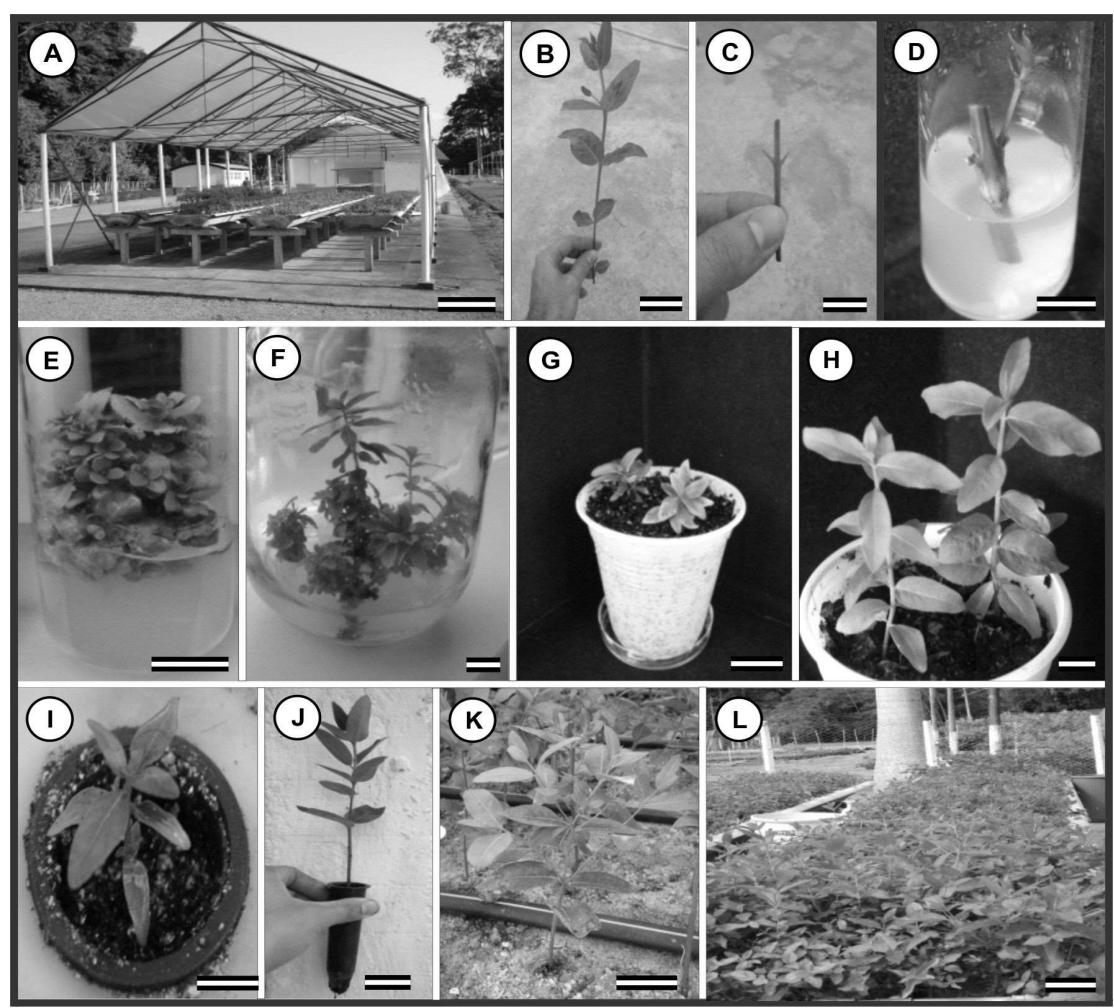

Figure 1 - General aspect of E. globulus hybrid clones micropropagated by axillary bud proliferation. (A) mini-clonal hedge $($ bar $=1 \mathrm{~m})$; (B) shoot collected from mini stumps for in vitro establishment (bar = 50 mm); (C) nodal segment used for in vitro establishment (bar $=10 \mathrm{~mm})$; (D) axillary shoot in nodal segment after 20 days established in vitro $($ bar $=10 \mathrm{~mm})$; (E) shoots from C04 clone in MS multiplication medium culture, after 30 days (bar $=10 \mathrm{~mm}) ;(\mathrm{F})$ elongated shoot $\mathrm{C} 16$ clone on MS medium culture after 30 days $($ bar $=10 \mathrm{~mm}) ;(\mathrm{G}, \mathrm{H})$ Detail of acclimatized micro-cuttings ( a $=10 \mathrm{~mm})$; (I) micro-cutting in greenhouse $($ bar $=10 \mathrm{~mm})$; $(\mathrm{J})$ rooted microcutting $($ bar $=50 \mathrm{~mm}) ;(\mathrm{K})$ micro stump in gutters containing sand (bar $=50 \mathrm{~mm})$; (L) micro-clonal hedge $($ bar $=50 \mathrm{~mm})$

Figura 1-Aspecto geral dos clones hibridos de E. globulus micropropagados via proliferação de gemas axilares. (A) minijardim clonal (barra =1m); (B) brotação coletada de minicepas para o estabelecimento in vitro (barra $=50 \mathrm{~mm})$; (C) segmento nodal utilizado para o estabelecimento in vitro (barra $=10 \mathrm{~mm}$ ); (D) brotação axilar em segmento nodal, 20 dias após o estabelecimento in vitro (barra $=10 \mathrm{~mm}) ;($ E) brotaçóes do clone C04 após 30 dias de cultivo in vitro no meio de cultura MS, (barra =10 mm); (F) brotação alongada do clone C16 após 30 dias de cultivo in vitro no meio de cultura MS (barra =10mm); $(G, H)$ Detalhe das microestacas aclimatizadas $($ barra $=10 \mathrm{~mm}) ;($ I) microestaca aclimatizada na casa de vegetação (barra $=10 \mathrm{~mm}) ;(\mathrm{J})$ microestaca enraizada $($ barra $=50 \mathrm{~mm}) ;(K)$ microcepa no canaletão de areia $($ barra $=50 \mathrm{~mm}) ;(L)$ microjardim clonal $($ barra $=$ $50 \mathrm{~mm})$.

Sigma Chemical Company, USA), and $5 \mu \mathrm{L}$ RNase (Amresco, USA) was added to each sample. Samples were incubated at $4{ }^{\circ} \mathrm{C}$ in the dark and examined after $1-2 \mathrm{~h}$.

At least 10,000 nuclei were analyzed in each sample. Analyses were performed using a FACS Calibur flow cytometer (Becton-Dickinson, NJ, USA) at the Biological Sciences Institute (ICB) of the Federal University of Juiz de Fora (UFJF). Cytometric histograms were generated and analyzed using Cell Quest and WinMDI 2.8 software (available at http://www.cyto.purdue.edu/ flowcyt/software/Winmdi.htm). Nuclear DNA content (pg) was estimated by the equation:

$$
\text { Sample (2C DNA })=\frac{\text { G1 peak channel of sample }}{\text { G1 peak channel sample of G. max }}
$$

x $2.50 \mathrm{pg}($ G. $\max$ DNA content $)$ 


\subsection{Microsatellite DNA markers analyses}

DNA extraction expanded leaves of mini-cuttings, micro-cuttings and in vitro plants of E. globulus hybrid clones, as well as the microsatellite markers used, were performed as previously described in Brondani et al. (1998 and 2006). Microsatellite genotyping was performed according to Faria et al. (2010).

\section{RESULTS}

The ploidy level of plants propagated via mini-cutting technique, micro-cutting technique and shoots maintained in the in vitro multiplication of three E. globulus hybrid clones of was assessed by flow cytometry. The DNA content of the nucleus of mature leaves of E. globulus hybrid clones was estimated. Peak G1 DNA content observed for all samples exhibited low coefficients of variation (1.89 to $2.54 \%$ ) enabling determination of ploidy level unequivocally (Table 1). This result showed that the whole of plants maintained the condition diploid suggesting stability in all three propagation methods.

The estimates of the DNA content (2C) for the hybrids were very similar between samples (low standard deviation) and, as expected, the values of DNA content ( 1.27 to $1.29 \mathrm{pg}$ ) were very close to those observed for the species used as the parent in crosses these hybrid clones. According to Praça et al. (2009), the three species used for hybrids investigated here have $1.34 \mathrm{pg}$ (E. urophylla), $1.33 \mathrm{pg}$ (E. grandis) and 1.09 to $1.40 \mathrm{pg}$ (E. globulus) DNA content. The DNA content (2C) species and hybrids of commercially important Eucalyptus ranges from 0.77 to $1.47 \mathrm{pg}$ (Grattapaglia and Bradshaw, 1994).
Therefore, in addition to evaluating the genetic variability of the three E. globulus hybrid clones were performed using thirteen microsatellite markers. Microsatellite markers had their loci amplified, and the primer pairs yielded reproducible 52 alleles ranging in size from 94 to 273 base pairs (Table 2). Allele sizes were very close to those found in the literature for Eucalyptus species.

EMBRA11,EMBRA63, EMBRA128 andEMBRA157 loci resulted in a profile with only one band (allele) for clone $\mathrm{C} 04$, an individual representing a homozygous diploid species. Similarly for EMBRA128 and EMBRA157 loci also resulted in a profile with one band (allele) for $\mathrm{C} 16$ and $\mathrm{C} 30$ clones. Furthermore, for $\mathrm{C} 30$ clone was observed for the same EMBRA63 locus (Table 2). The remaining loci resulted in banding patterns with two bands representing a heterozygous individual.

Microsatellite markers results revealed that all pairs of primers produce amplified products with monomorphic similar patterns for clones. In the study changes to the DNA clones in different propagation techniques were not detected, revealing that the micropropagation did not induce genetic changes (Table 2). Differences in patterns of primer pairs were only detected among clones, indicating that there are genetic differences between these genetic materials

In the present study, the number of in vitro subcultures performed ( 25 subcultures) did not induce somaclonal variation detectable by evaluation methods adopted. These results reflect the genetic stability of E. globulus hybrid clones micropropagated, compared to plant material from mini stumps. However, do not

Table 1 - Mean DNA content as determined by flow cytometry analysis of two Eucalyptus urophylla x E. globulus (C04 e C16) clones and a Eucalyptus grandis x E. globulus (C30) clone derived from mini-cutting technique, microcutting technique and in vitro culture

Tabela 1 - Conteúdo médio de DNA determinado pela análise de citometria de fluxo de dois clones de Eucalyptus urophylla $x$ E. globulus (C04 e C16) e um clone de Eucalyptus grandis $x$ E. globulus (C30) propagados por miniestaquia, microestaquia e cultivo in vitro.

\begin{tabular}{cccc}
\hline Clone & Plant origin & DNA content $(\mathrm{pg})^{\mathrm{a}}$ & CV (\%) \\
\hline C04 & Mini-cutting & $1.27 \pm 0.007$ & 2.21 \\
& Micro-cutting & $1.29 \pm 0.010$ & 2.19 \\
& In vitro plants & $1.28 \pm 0.010$ & 1.89 \\
\hline C16 & Mini-cutting & $1.28 \pm 0.007$ & 2.54 \\
& Micro-cutting & $1.28 \pm 0.010$ & 2.32 \\
& In vitro plants & $1.29 \pm 0.017$ & 2.18 \\
\hline C30 & Mini-cutting & $1.28 \pm 0.021$ & 2.54 \\
& Micro-cutting & $1.28 \pm 0.010$ & 2.43 \\
& In vitro plants & $1.27 \pm 0.017$ & 2.43 \\
\hline
\end{tabular}

${ }^{\mathrm{a}}$ Mean \pm standard deviation. 
Table 2 - Allele size of the 13 microsatellite loci amplified in two Eucalyptus urophylla x E. globulus (C04 e C16) clones and a Eucalyptus grandis x E. globulus (C30) clone from mini-cutting technique, micro-cutting technique and in vitro culture.

Tabela 2 - Tamanho do alelo de 13 locus amplificados de marcadores microssatélites em dois clones de Eucalyptus urophylla $x$ E. globulus (C04 e C16) e um clone de Eucalyptus grandis $x$ E. globulus (C30) propagados por miniestaquia, microestaquia e cultivo in vitro.

\begin{tabular}{|c|c|c|c|c|c|c|c|c|c|}
\hline \multirow[t]{3}{*}{ Locus } & \multicolumn{9}{|c|}{ Allele size (bp) } \\
\hline & \multicolumn{3}{|c|}{$\mathrm{C04}$} & \multicolumn{3}{|c|}{$\mathrm{C} 16$} & \multicolumn{3}{|c|}{ C30 } \\
\hline & $\begin{array}{l}\text { Mini- } \\
\text { cutting }\end{array}$ & $\begin{array}{l}\text { Micro- } \\
\text { cutting }\end{array}$ & $\begin{array}{l}\text { In vitro } \\
\text { plants }\end{array}$ & $\begin{array}{l}\text { Mini- } \\
\text { cutting }\end{array}$ & $\begin{array}{l}\text { Micro- } \\
\text { cutting }\end{array}$ & $\begin{array}{l}\text { In vitro } \\
\text { plants }\end{array}$ & $\begin{array}{l}\text { Mini- } \\
\text { cutting }\end{array}$ & $\begin{array}{l}\text { Micro- } \\
\text { cutting }\end{array}$ & $\begin{array}{l}\text { In vitro } \\
\text { plants }\end{array}$ \\
\hline EMBRA3 & $110 / 168$ & $110 / 168$ & $110 / 168$ & $110 / 181$ & $110 / 181$ & $110 / 181$ & $112 / 168$ & $112 / 168$ & $112 / 168$ \\
\hline EMBRA11 & 125 & 125 & 125 & $121 / 125$ & $121 / 125$ & $121 / 125$ & $123 / 135$ & $123 / 135$ & $123 / 135$ \\
\hline EMBRA12 & $137 / 145$ & $137 / 145$ & $137 / 145$ & $126 / 132$ & $126 / 132$ & $126 / 132$ & $117 / 130$ & $117 / 130$ & $117 / 130$ \\
\hline EMBRA28 & $172 / 199$ & $172 / 199$ & $172 / 199$ & $189 / 217$ & $189 / 217$ & $189 / 217$ & $199 / 212$ & $199 / 212$ & $199 / 212$ \\
\hline EMBRA38 & $94 / 145$ & $94 / 145$ & $94 / 145$ & $107 / 145$ & $107 / 145$ & $107 / 145$ & $109 / 111$ & $109 / 111$ & $109 / 111$ \\
\hline EMBRA44 & $185 / 210$ & $185 / 210$ & $185 / 210$ & $197 / 210$ & $197 / 210$ & $197 / 210$ & $185 / 197$ & $185 / 197$ & $185 / 197$ \\
\hline EMBRA63 & 184 & 184 & 184 & $170 / 187$ & $170 / 187$ & $170 / 187$ & 175 & 175 & 175 \\
\hline EMBRA128 & 117 & 117 & 117 & 103 & 103 & 103 & 126 & 126 & 126 \\
\hline EMBRA157 & 144 & 144 & 144 & 141 & 141 & 141 & 125 & 125 & 125 \\
\hline EMBRA204 & $134 / 148$ & $134 / 148$ & $134 / 148$ & $124 / 148$ & $124 / 148$ & $124 / 148$ & $136 / 138$ & $136 / 138$ & $136 / 138$ \\
\hline EMBRA219 & $258 / 273$ & $258 / 273$ & $258 / 273$ & $247 / 265$ & $247 / 265$ & $247 / 265$ & $254 / 259$ & $254 / 259$ & $254 / 259$ \\
\hline EMBRA333 & $228 / 234$ & $228 / 234$ & $228 / 234$ & $217 / 230$ & $217 / 230$ & $217 / 230$ & $211 / 216$ & $211 / 216$ & $211 / 216$ \\
\hline EMBRA681 & $218 / 252$ & $218 / 252$ & $218 / 252$ & $217 / 263$ & $217 / 263$ & $217 / 263$ & $217 / 252$ & $217 / 252$ & $217 / 252$ \\
\hline
\end{tabular}

rule out the possibility of somaclonal variation occurrence in other microsatellites not included in this study, because the individual information provided by microsatellites is restricted (Fernandes et al., 2011).

As demonstrated for other species, the combined use of flow cytometry and microsatellite markers has been used successfully in the E. globulus hybrid clones to demonstrate that the micropropagation protocol described did not induce genetic variability, ensuring their genetic fidelity. According to the literature this is the first study that has evaluated and confirmed the genetic stability of material propagated via microcutting of E. globulus hybrid clones using flow cytometry and microsatellite markers. Particularly in this case, the detection of a possible genetic variation is important, of forest breeding program of company, in order to increase the clonal plantations productivity, quality and wood uniformity for high quality pulp production.

\section{DISCUSSION}

The visual assessment of phenotypic clones showed no variability of micropropagated plants (micro-stumps) compared to mini-stumps, concerning the behavior of growth and leaf morphology in the nursery. In in vitro culture, micropropagated clones also showed normal morphology, suggesting that the axillary bud proliferation assured genetic integrity of micropropagated shoots. However, the absence of visual variations not proves the lack of variation among micropropagated plants (Bindiya and Kanwar, 2003).

In a wide variety of plant species, aneuploidy and/ or changes in ploidy level has been considered the major changes that occur as the somaclonal variation (Rani and Raina, 1998). According Endemann et al. (2001), polyploidization is result of prolonged in vitro culture, unfavorable in vitro conditions, or the action of substances which affect metabolism, growth and development of plant.

Flow cytometry has been widely used to detect variation in ploidy level of plants micropropagated because of relatively low cost, high yield and precision of analysis (Rahman and Rajora, 2001; Loureiro et al., 2007; Mallón et al., 2010). Brito et al. (2010) found no genetic variation when two wild olives (Olea maderensis L. and O. europaea spp. Europaea var. sylvestris) were micropropagated through axillary bud proliferation, both species with the same ploidy level of parent trees in the field. The successful use of flow cytometry to assess the level of ploidy has been reported in Quercus suber (Loureiro et al., 2005), Juniperus phoenica (Loureiro et al., 2007) and E. globulus (Azmi et al., 1997; Pinto et al., 2004). 
However, the absence of changes in ploidy level by flow cytometry does not rule out the occurrence of genetic differences at a molecular level with mutations in DNA (Loureiro et al., 2005; Orbovic et al., 2008; Mallón et al., 2010). Thus, understands that genetic analyzes by flow cytometry and microsatellite markers complement each other, giving greater reliability to the results obtained with these techniques.

Microsatellite loci consisting of preferred mutation sites of the genome (Brito et al., 2010), so due to the absence of somaclonal variation in thirteen microsatellite tested in this study. We can be concluded that the results obtained by micropropagation protocol employed did not induce somaclonal variation in clones for these specifics microsatellites. Similarly, the absence of somaclonal variation was observed for microsatellite markers in Camellia spp. three varieties (Borchetia et al., 2009) and Prunus dulcis (Martins et al., 2004).

In general, the possibility of occurrence of the somaclonal variation occurs more frequently in propagation systems involving the growth of cells disorganized (Cooper et al,. 2006; Bairu et al., 2011). Cloning from well-organized structures such as meristems like in this study, are genetically stable (Bhatia et al., 2009, 2011; Memon et al., 2012). The findings agree with the fact that the micropropagation through axillary bud proliferation is one of the safest methods for the production of genetically identical plants to the mother plant. There are several works in literature which obtained similar results (Rani and Raina, 1998; Martins et al., 2004; Renau-Morata et al., 2005; Joshi and Dhawan, 2007; Borchetia et al., 2009; Brito et al., 2010; Nayak et al., 2011; Leva and Petruccelli, 2012).

Genotype is considered as the most important factor for the occurrence of somaclonal variation, which may influence the phenotypic stability of the plants obtained (Zucchi et al., 2002; Shen et al., 2007). Tremblay et al. (1999) noted that the occurrence of somaclonal variation was strongly influenced by genotype in two species of Picea. Although, specifically for Eucalyptus, this has low vulnerability to phenotypic changes in the number and ploidy due to in vitro culture, biochemicals action or stress (Rani and Raina, 1998).

Regarding the number of microsatellites markers used in this study (13), this was similar or very close to those found in other studies that also aimed to assess the genetic stability of micropropagated plants. The evaluation of the genetic stability of Populus tremuloides was performed using 10 microsatellites (Rahman and Rajora, 2001). In the assessment of the genetic stability of three varieties of Camellia spp., Quercus suber L. somatic embryos and Olea maderensis and O. europaea ssp. europaea var. sylvestris were performed using 12, 8 and 10 microsatellites, respectively (Lopes et al., 2006; Borchetia et al., 2009; Brito et al., 2010).

\section{CONCLUSION}

The micropropagated E. globulus hybrid clones showed genetical stability by flow cytometry and microsatellite markers.

The micropropagation with purposes of rejuvenation can be a viable technique to obtain genetically true to type E. globulus hybrid clones.

\section{ACKNOWLEDGMENTS}

The authors would like to thank CNPq, FAPEMIG e CENIBRA for financial support, and the latter also providing the genetic material. We also thank the Biological Sciences Institute (ICB) of the Federal University of Juiz de Fora (UFJF) by flow cytometry analyzes.

\section{REFERENCES}

Agarwal M, Shrivastava N, Padh H. Advances in molecular marker techniques and their applications in plant sciences. Plant Cell Reports. 2008;27:617-31.

Azmi A, Noin M, Landré P, Proteau M, Boudet AM, Chriqui D. High frequency plant regeneration from Eucalyptus globulus Labill. hypocotyls: Ontogenesis and ploidy level of the regenerants. Plant Cell Tissue and Organ Culture. 1997;51(1):9-16.

Bairu MW, Fennell CW, van Staden J. The effect of plant growth regulators on somaclonal variation in Cavendish banana (Musa AAA cv. 'Zelig'). Scientia Horticulturae. 2006;108:347-51.

Bairu MW, Bairu AOA, van Staden J. Somaclonal variation in plants: causes and detection methods. Plant Growth Regulators, 2011;63:147-73. 
Bhatia R, Singh KP, Sharma TR, Jhang T. Evaluation of the genetic fidelity of in vitropropagated gerbera (Gerbera jamesonii Bolus) using DNA-based markers. Plant Cell, Tissue and Organ Culturae. 2011;104:131-5.

Bhatia R, Singh KP, Jhang T, Sharma TR. Assessment of clonal fidelity of micropropagated gerbera plants by ISSR markers. Scientia Horticulturae. 2009;119:208-11.

Bindiya K, Kanwar K. Random amplified polymorphic DNA (RAPDs) markers for genetic analysis in micropropagated plants of Robinia pseudoacacia L. Euphytica. 2003;132:41-7.

Borchetia S, Das SC, Handique PJ, Das S. High multiplication frequency and genetic stability for commercialization of the three varieties of micropropagated tea plants (Camellia spp.). Scientia Horticulturae. 2009;120:544-50.

Borges SR, Xavier A, Oliveira LS, Lopes AP, Otoni WC. Multiplicação in vitro de clones híbridos de Eucalyptus globulus. Revista Árvore. 2011;35(3):425-34.

Brito G, Lopes T, Rodriguez JLE, Santos C. Assessment of genetic stability of two micropropagated wild olive species using flow cytometry and microsatellite markers. Trees. 2010;24:723-32.

Brondani RPV, Brondani C, Tarchini R, Grattapaglia D. Development, characterization and mapping of microsatellite markers in Eucalyptus grandis and E. urophylla. Theoretical and Applied Genetics. 1998;97:816-27.

Brondani RPV, Williams E, Brondani C, Grattapaglia D. A high coverage microsatelliteonly consensus linkage map for Eucalyptus species and a novel set of 230 microsatellite markers for the genus. BMC Plant Biology. 2006;6(20):1-16.

Chandryka M, Ravishankar R, Thoyajaksha V. ISSR marker based analysis of micropropagated plantlets of Nothapodytes foetida. Biologia Plantarum. 2010;54:561-5.

Conde P, Loureiro J, Santos C. Somatic embryogenesis and plant regeneration from leaves of Ulmus minor Mill. Plant Cell Reports. 2004;22:632-9.

Cooper C, Crowther T, Smith BM, Isaac S, Collin HA. Assessment of the response of carrot somaclones to Pythium violae, causal agent of cavity spot. Plant Pathology. 2006;55:427-32.

Doležel J, Bartoš J. Plant DNA flow cytometry and estimation of nuclear genome size. Annals Botany. 2005;95:99-110.

Doležel, J, Doleželová, M, Novák, F. Flow cytometric estimation of nuclear DNA amount in diploid bananas (Musa acuminata and $\mathrm{M}$. balbisiana). Biologia Plantarum, 1994: 36; 351-57

Endemann M, Hristoforoglu K, Stauber T, Wilhelm E. Assessment of age-related polyploidy in Quercus robur L. somatic embryos and regenerated plants using DNA flow cytometry. Biologia Plantarum. 2001;44:339-45.

Faria DA, Mamani EMC, Pappas MR, Pappas GJ, Grattapaglia D. A selected set of EST-derived microsatellites, polymorphic and transferable across 6 species of Eucalyptus. Journal of Heredity. 2010;101(4):512-20.

Fernandes P, Rocha ACC, Santos C. Genetic stability evaluation of Quercus suber L. somatic embryogenesis by RAPD analysis. Pakistan Journal of Botany. 2011;43:2727-31.

Gomes F, Canhoto JM. Micropropagation of Eucalyptus nitens Maiden (shining gum). In Vitro Cellular and Developmental Biology-Plant. 2003;39:316-21.

Grattapaglia D, Bradshaw HD. Nuclear DNA content of commercially important Eucalyptus species and hybrids. Canadian Journal of Forest Research. 1994;24:1074-8.

Jackson AL, Ru C, Lawrence LA. Induction of microsatellite instability by oxidative DNA damage. Proceedings of the National Academy of Science of the United States of America. 1998;95:12468-73.

Jin S, Mushke R, Zhu H, Tu L, Lin Z, Zhang Y et al. Detection of somaclonal variation of cotton (Gossypium hirsutum) using cytogenetics, ûow 
cytometry and molecular markers. Plant Cell Reports. 2008;27:1303-16.

Joshi P, Dhawan V. Assessment of genetic fidelity of micropropagated Swertia chirayita plantlets by ISSR marker assay. Biologia Plantarum. 2007;51:22-6.

Leva AR, Petruccelli R. Monitoring of cultivar identity in micropropagated olive plants using RAPD and ISSR markers. Biologia Plantarum. 2012;56:373-6.

Lopes T, Capelo A, Brito G, Loureiro J, Santos C. Genetic variability analyses of the somatic embryogenesis induction process in Olea spp. using nuclear microsatellites. Trees. 2009;23:29-36.

Lopes T, Pinto G, Loureiro J, Costa A, Santos C. Determination of genetic stability in long-term somatic embryogenic cultures and derived plantlets of cork oak using microsatellite markers. Tree Physiology. 2006;26:1145-52.

Loureiro J, Pinto G, Lopes T, Dolezel J, Santos C. Assessment of ploidy stability of the somatic embryogenesis process in Quercus suber L. using flow cytometry. Planta. 2005;221:815-22.

Loureiro J, Capelo A, Brito G, Rodriguez E, Silva S, Pinto G et al. Micropropagation of Juniperus phoenicea from adult plant explants and analysis of ploidy stability using flow cytometry. Biologia Plantarum. 2007;51:7-14.

Mallón R, Rodríguez-Oubiña J, González ML. In vitro propagation of the endangered plant Centaurea ultreiae: assessment of genetic stability by cytological studies, flow cytometry and RAPD analysis. Plant Cell Tissue and Organ Culture. 2010;101:31-39.

Mankessi F, Saya A, Baptiste C, NourissierMountou S, Monteuuis O. In vitro rooting of genetically related Eucalyptus urophylla $\times$ Eucalyptus grandis clones in relation to the time spent in culture. Trees. 2009;23:931-40.

Martins M, Sarmento D, - Oliveira MM. Genetic stability of micropropagated almond plantlets, as assessed by RAPD and ISSR markers. Plant Cell Reports. 2004;23:492-6.
Memon N. Qasim M, Jaskani MJ, Awan FS, Jaffar M, Khan AI et al. Assessement of somaclonal variation in in vitro propagated cormels of gladiolus. Pakistan Journal of Botany. 2012;44:769-76.

Modgil M, Mahajan K, Chakrabarti SK, Sharma DR, Sobti RC. Molecular analysis of genetic stability in micropropagated apple rootstock MM106. Scientia Horticulturae. 2005;104:151-60.

Murashige T. Skoog F. A revised medium for rapid growth and bioassoys with tobacoo tissue culture. Physiology Plantarum. 1962;15:473-97.

Nayak S, Kaur T, Mohanty S, Ghosh G, Choudhury R, Acharya L. et al. In vitro and ex vitro evaluation of long-term micropropagated turmeric as analyzed through cytophotometry, phytoconstituents, biochemical and molecular markers. Plant Growth Regulators. 2011;64:91-8.

Negi D, Saxena S. Ascertaining clonal ûdelity of tissue culture raised plants of Bambusa balcooa Roxb. using inter simple sequence repeat markers. New Forests. 2010;40:1-8.

Orbovic V, Calovic M, Viloria Z, Nielsen B, Gmitter FG Jr, Castle WS.et al. Analysis of genetic variability in various tissue culture-derived lemon plant populations using RAPD and ûow cytometry. Euphytica. 2008;161:329-35.

Peredo EL, Arroyo-Garcia R, Revilla MA. Epigenetic changes detected in micropropagated hop plants. Journal Plant Physiology. 2009;166(10):1101-11.

Phillips RL, Kaeppler SM, Olhoft P. Genetic instability of plant tissue cultures: Breakdown of normal controls. Proceedings of the National Academy of Science of the United States of America. 1994;91:5222-6.

Pinto G, Loureiro J, Lopes T, Santos C. Analysis of the genetic stability of Eucalyptus globulus Labill. somatic embryos by flow cytometry. Theoretical and Applied Genetics. 2004:109:580-7.

Praça MM, Carvalho CR, Novaes CRDB. Nuclear DNA content of three Eucalyptus species estimated by flow and image cytometry. Australian Journal of Botany. 2009;57:524-31.

Revista Árvore. 2017;41(1):e410114

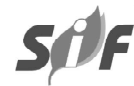


Rahman MH, Rajora OP. Microsatellite DNA somaclonal variation in micropropagated trembling aspen (Populus tremuloides). Plant Cell Reports. 2001;20:531-6.

Rani V, Raina SN. Genetic analysis of enhancedaxillary-branching-derived Eucalyptus tereticornis Smith and E. camaldulensis Dehn plants. Plant Cell Reports. 1998;17:236-42.

Rani V, Raina SN. Genetic fidelity of organized meristem- derived micropropagated plants: a critical appraisal. In Vitro Cellular and Developmental Biology-Plant. 2000;36:319-30.

Renau-Morata B, Nebauer SG, Arrillaga I, Segura J. Assessments of somaclonal variation in micropropagated shoots of Cedrus: consequences of axillary bud breaking. Tree Genetics \& Genomes. 2005;1:3-10.

Shen X, Chen J, Kane ME, Henny RJ. Assessment of somaclonal variation in Dieffenbachia plants regenerated through indirect shoot organogenesis. Plant Cell Tissue and Organ Culture. 2007;91:21-27.

Tremblay L, Levasseur CT, Remblay FM. Frequency of somaclonal variation in plants of black spruce (Picea mariana, Pinaceae) and white spruce ( $P$. glauca, Pinaceae) derived from somatic embryogenesis and identification of some factors involved in genetic instability. American Journal of Botany. 1999;86:1373-81.

Tripathi SB, Mathish NV, Gurumurthi K. Use of genetic markers in the management of micropropagated Eucalyptus germplasm. New Forests. 2006;31:361-72.

White PR. Further evidence on the significance of glycine, pyridoxine and nicotinic acid in the nutrition of excised tomato roots. American Journal of Botany. 1943;30:33-6.

Wilhelm E, Hristoforoglu K, Fluch S, Burg K. Detection of microsatellite instability during somatic embryogenesis of oak (Quercus robur L.) Plant Cell Reports. 2005;23:790-5.

Xavier A, Wendling I, Silva RL. Silvicultura clonal: princípios e técnicas. $2^{\mathrm{a}}$.ed. Viçosa, $\mathrm{MG}$ : Universidade Federal de Viçosa; 2013. 279p.

Zucchi MI, Arizono H, Morais VI, Fungaro MHP, Vieira MLC. Genetic instability of sugarcane plants derived from meristem cultures. Genetics and Molecular Biology. 2002;25:91-6. 